\title{
A Study of IPO Underpricing Using Regression Model Based on Information Asymmetry, Media, and Institution
}

\author{
Liangda Liu ${ }^{1, a,{ }^{\dagger}}$ Zixuan Zhang ${ }^{2, b, \dagger}$ Kexin Lyu ${ }^{3, *, c, \dagger}$
}

\author{
${ }^{1}$ Jinan University, Guangzhou, China \\ ${ }^{2}$ University of British Columbia, Beijing, China \\ ${ }^{3}$ Southwestern University of Finance and Economics, Sichuan, China \\ *Corresponding author. Email: ${ }^{a}$ a402103080@163.com, ${ }^{b}$ woshizhuzhangzixuan@126.com \\ clvkaycee0506@smail.swufe.edu.cn \\ These authors contributed equally.
}

\begin{abstract}
This paper reviews the empirical studies of IPO underpricing, with an emphasis on Chinese stock market. It surveys the driving factors of IPO underpricing using the fitting regression analysis and disaggregate model. The studies have been sorted into three categories: information asymmetry, media coverage, and institutional factors. From the information asymmetry, this paper reviews five information asymmetry theories and uses the empirical analysis of the Winner's Curse as the basis. It also lists the implications of some information asymmetry theories on various fields in the economy. In terms of media coverage, we used control variate model to analyse influence of each factor. It has been found that both media attention and media tone will affect investor sentiment and thus affect IPO underpricing. Therefore, to reduce the IPO underpricing rate, enterprises can carry out media information management to increase the proportion of negative tone in media reports. In the last section, we use linear regression model and discovered that IPO underpricing phenomenon was significantly correlated with institutional control and speculation behavior.
\end{abstract}

Keywords: IPO underpricing, information asymmetry theory, Investor sentiment theory, government control.

\section{INTRODUCTION}

The phenomenon of IPO underpricing refers to that the market trading price of the initial public offering stock after listing (generally refers to the first day) is substantially higher than the offering price, and there is a huge price gap between the issuing market and the trading market, resulting in a significant positive excess return of the initial public offering. IPO underpricing is widespread in the capital markets of various countries, including China, and has caused domestic and foreign scholars to actively explore its causes, trying to explain this phenomenon theoretically and empirically from different aspects $[1,2]$. Ibbotson and his coauthor found for the first time that IPO underpricing is widespread, but they cannot provide a convincing explanation for this phenomenon $[3,4]$. Many scholars have explored the causes of IPO underpricing from different perspectives. This paper reviews the empirical studies of IPO underpricing, with an emphasis on Chinese stock market. The research object is the factors that cause IPO underpricing.

The related studies are categorized into three directions: information asymmetry, media coverage, and institutions. Section one studies the information asymmetry theory, it introduces the five schools of five information asymmetry theories and uses the empirical analysis of the Winner's Curse as the basis. It also lists the impact of some information asymmetry theories on various fields in the actual market. Section two switches to media coverage. In terms of media coverage, this research finds that both media attention and media tone will affect investor sentiment and thus affect IPO underpricing. Therefore, to reduce the IPO underpricing rate, enterprises can carry out media information management to increase the proportion of negative tone in media reports. Last section is the policy part which find that IPO underpricing phenomenon in China was significantly correlated with institutional control and 
speculation behavior. The SSE STAR market is a pilot for China's capital market reform, in the direction of marketization reform in the distribution system, so the STAR market distribution system influence on IPO underpricing rate, is to win the board reform achievements inspection, for through the reform of the system solve the problem of high rate of IPO underpricing, and judge STAR market system reform to the feasibility of the A-share market is important meaning.

\section{INFORMATION ASYMMETRY}

This section surveys the information asymmetry channel of the IPO underpricing. Information asymmetry is the total transaction when one of the two sides can only obtain incomplete information. Information asymmetry is one of the most popular explanation for IPO underpricing. Within this framework, the IPO market is believed to be efficient. The stock market price reflects its true value. IPO underpricing refers to the phenomenon of issuing shares at a price lower than the true value. The reason is the information asymmetry among market participants (issuer, underwriter, and investor). However, Tang and Luan shou us that some researchers have different opinions on the forms of asymmetric information, so they put forward their different explanatory viewpoints [5].

\subsection{The development of the information asymmetry expalnation}

\subsubsection{Winner's Curse}

Rock believes that investors as a whole have more information than issuers, but investors are divided into two groups: informed investors and uninformed investors $[6,7]$. Informed investors know exactly the true value of the stock, and only when the issue price is less than the value of the stock, the informed investor will participate in the subscription. Obviously, the successful subscription rate of unknown investors will change due to whether informed investors participate in the subscription. When the issue price is higher than the value of the stock, "informed investors abandon the subscription of new shares" so that the success rate of unknown investors increases, and vice versa. This result puts unknown investors into the dilemma of the "Winner's Curse", resulting in their lack of enthusiasm to subscribe for new stocks. Issuers need the participation of all types of investors to ensure the success of the issuance of new shares, so the IPO stock issuance price must be set at a level lower than the expected value of the stock, that is, to attract unknown investors through IPO underpricing. The first evidence for this explanation comes from the study of Koh and Walter [8]. They found that in the Singapore market, the underpricing of IPO stocks averaged $27 \%$, but the subscription income of unknown investors was only weighted by the success rate. Is $1 \%$. Levis and Keloharju conducted empirical studies on the UK and Finland and obtained similar results $[9,10]$.

\subsection{2 "Information Cascade" commentary.}

Welch believes that investors as a whole have an information advantage, but each investor has only one piece of "good" or "bad" private information, without knowing the exact value of IPO stocks [11]. Welch pointed out that due to the long duration of subscription of new shares, it shows the characteristics of sequential subscription. Subsequent investors will use the behavior of the first investors to infer their information and update their own value expectations. Therefore, the behavior of the first investor will affect the decision of subsequent investors and gradually increase with the extension of the subscription sequence. In the end, the private information of the subsequent investor will become irrelevant. The subscription or not depends entirely on the behavior of the first investor. Welch called this phenomenon "Information cascade", and pointed out that this is the result of investors' rational reaction in an asymmetric information environment, which is fundamentally different from the "herd behavior" contagious by emotions. In order to avoid the failure of the issuance, the issuer must use IPO underpricing to promote a favorable "information connection" (that is, subsequent investors actively participate in the subscription). The direct evidence for this explanation is the empirical research provided by Amihud et al. on the Tel Aviv stock market [12]. They found that the demand for new stock subscriptions is either extremely strong or obviously insufficient. There are few intermediate situations, which confirms the existence of "information cascade". Amihud et al. also found that the "Winner's Curse" phenomenon also exists in the Tel Aviv securities market [12]. Although the average IPO underpricing in the market is as high as $12 \%$, the subscription yield of unknown investors is negative after the winning rate is weighted value.

\subsection{3. "Information Disclosure" commentary.}

Benveniste and Spindt believe that investors as a whole have information advantages, but only institutional investors have private information. Retail investors are unknown investors [13]. In the "roadshow" stage, the underwriters designed a set of information screening mechanism to collect private information from institutional investors to provide a reference for the pricing of new shares. of course, this mechanism must meet the conditions for investors to "tell the truth". According to the Benveniste and Spindt model (BS model henceforth), to meet this condition, the issuer needs to issue shares with a certain underpricing range and give priority to allocating shares to institutions that disclose 
"good" information. Benveniste and Wilhelm expanded the BS model from the perspective of issuance regulation, pointing out that the regulation of discriminatory pricing behavior is the cause of IPO underpricing [14]. If discriminatory allotment is also regulated, the issuance of new shares will fall into the "Winner's Curse" dilemma. Sherman and Titman extended the BS model from the perspective of information cost, stating that the information screening mechanism should not only meet the incentive conditions of "telling the truth", but also compensate the production cost of investor information [15]. Hanley found that the pricing of new stocks has insufficient adjustment to "good" information, indicating that IPO underpricing is a mechanism arrangement for issuers to encourage investors to truly disclose "good" information [16]. Corneli and Goldreich provided direct empirical support for the explanation [17,18]. They found that limit orders received 19\% more share placements than market orders. The tilt of placements to limit orders obviously encourages investors to disclose information. Limit orders contain more information than market orders

\subsection{4 "Authorized Agent" commentary.}

Baron and Homstrom and Baron believe that the interests of issuers and underwriters are not consistent: on the one hand, underwriters can lower the issue price to reduce the difficulty of stock distribution and underwriting costs $[19,20]$; on the other hand, the use of priority placement of underpriced stocks can be Cater to specific customer groups for long-term benefits. Therefore, there is a principal-agent conflict between the issuer and the underwriter. According to the Baron model, issuers at an information disadvantage cannot fully supervise the underwriters [20]. They can only choose a sub-optimal mechanism to reduce the "principal-agent" conflict between the two parties. IPO underpricing is the essential content of this sub-optimal mechanism. The empirical research has completely disagreements on the test results of this explanation. Muscarella and Vetsuypens examined the selfunderwriting and listing of 38 investment banks, and found that the underpricing range did not allow other stocks at all [21]. This obviously does not support the "principal agent" explanation, because these stocks do not have a principal-agent conflict. IPO underpricing The amplitude should be low or even non-existent. on the contrary, Ljungqvist and Wilhelm provided empirical support for this explanation [22]. They regard the proportion of manager shareholders' shareholding as an indicator of the intensity of supervision of underwriters. They found that the higher the proportion of manager's shareholders, the higher the shareholding ratio of IPO shares Lower amplitude.

\subsection{5. "Signal sending" commentary.}

Allen and Faulhaber believe that the issuer has an information advantage [23]. The reason is that insiders know the company better than investors. When it is impossible to distinguish differences in corporate performance, investors' willingness to pay for all stocks is the same, which is not conducive to issuers of blue-chip stocks, so they have the motivation to pass information to external investors. Based on this thinking, Allen and Faulhaber put forward the explanation of "signaling", they believe that the issuer is not pursuing the first issuance income but the maximization of the sum of the multi-stage issuance income [23]. At the time of the initial issuance, the issuer of high-performance stocks will strategically select the magnitude of the IPO underpricing and the issuance ratio to send a signal to the outside world to distinguish it from issuers of underperforming stocks. The precondition for this signal to be effective is that the issuer of under-performing stocks must imitate It becomes unprofitable. The issuer of bluechip stocks confirmed by investors can obtain a better issuance price in subsequent stock issuances. Welch put forward the explanation of "signaling" in the same period, and their views are roughly the same [24]. The empirical study of Jegadessh et al. show that although there is a positive relationship between the probability and size of secondary issuance (SEO) and the magnitude of IPO underpricing, the significance is relatively poor [25].

\subsection{An empirical study of IPO underpricing in China}

Based on the "Winner's Curse" first proposed by Rock and the risk hypothesis proposed by Ritter and Beatty on this basis, Zhang and Lu take 859 IPOs in the Chinese market from 2000 to May 2010 as a sample, under the conditions of controlling the overall market price-earnings ratio and overall market return on the first day of IPOs, for the first time, the standard deviation of the first day of sample IPO split returns is used as the preIPO standard deviation of the sample IPOs [26]. The proxy variable of market risk, the winning rate is the proxy variable of the imbalance between supply and demand in the IPO primary market. Through the establishment of a simple multiple regression empirical model, the "Winner's Curse" hypothesis first proposed by Rock and Ritter, Beatty, etc. are based on the "Winner's Curse" The hypothesis-expanded risk hypothesis has been tested empirically in explaining the effectiveness of the first-day IPO underpricing rate in the Chinese market during the sample period.

Furthermore, Liu and Chen aim to use the data of China's A-share issuance to test the IPO underpricing theory based on information asymmetry [27]. The empirical results show that it is effective to use the 
information asymmetry theory to explain the IPO underpricing phenomenon under the Chinese inquiry system.

In the case of full disclosure of information, the result of the bidding is that high-quality companies are reasonably priced and a high proportion of subscriptions, while companies with poor performance often fail to issue due to insufficient subscription or low bidding. The issue price and secondary market formed by the bidding principle There should be no large spreads between transaction prices.

Due to the increased risk of investors in the primary market, they will make cautious decisions when subscribing to stocks. In this decision-making process, the cost of information search is a key factor.

If the company can reduce the cost of information search for investors, that is, improve information transparency, it will minimize the difference in information held by all parties involved in the IPO, and the pricing of new shares will be fairer.

It can be considered that, as the degree of information asymmetry decreases, IPO underpricing will decrease, and IPO efficiency will increase.

Therefore, "how to reduce information asymmetry" to improve the transparency of the securities market, so that the IPO pricing more truly reflects the value of the issuing company, is an inevitable requirement for the healthy development of the securities market, and is also the research goal of the majority of researchers.

\subsection{The Influence of Information Asymmetry Theory in Different Fields on IPO Underpricing}

\subsubsection{Accounting conservatism}

Based on four regional factors, namely sales growth, company duration, company size, and corporate governance, Chen Liang uses the median of the sample of each regional proxy variable to divide the total sample into high-information asymmetry samples and lowinformation asymmetry samples [28]. High sales growth, short company duration, small company scale, and incomplete corporate governance are classified as companies with a high degree of information asymmetry. The author found through empirical analysis that accounting conservatism can help reduce the degree of information asymmetry and suppress IPO underpricing. For companies with a higher degree of information asymmetry, the negative correlation between accounting conservatism and IPO underpricing is more obvious. Due to the serious information asymmetry, it is very necessary to adopt the accounting conservatism principle in our country.

\subsubsection{Marketization Process and IPO Underpricing}

Information Asymmetry is that companies with undervalued and good yields tend to have lower winning rates, because both informed and uninformed investments will participate in the purchase; only uninformed investors will subscribe for those with overvalued and uninformed yields. For the best stocks, the winning rate of this type of stock is higher. It can be seen that the "Winner's Curse" theory from Levis believes that the winning rate is negatively related to IPO underpricing [29]. From Liu and Li information asymmetry in regions with a slower marketization process is more serious, and informed investors are more likely to use the information resources in their hands to purchase high-quality stocks, thereby reducing the winning rate of these companies [30]. Therefore, based on the "Winner's Curse" theory, it can be known that if price compensation to uninformed investors in a region with a low marketization process is the cause of high underpricing for IPO companies in the region, then IPO companies in that region should behave Lower winning rate

\subsection{Summary}

A brief review and prospects of China's IPO underpricing research. Although the "Winner's Curse", "signal cascading" and "information disclosure" explanations in the asymmetric information school have received empirical support, they are only necessary conditions for the theoretical explanation to be established, which are by no means sufficient. Moreover, empirical research itself is constantly deepening. The emergence of new empirical results may cause people to re-examine those theories that have received empirical support. The empirical results of Purnanandam and Swaminathan show that, from 1980 to 1997 , the issue price of IPO stocks in the US market was $50 \%$ higher than the trading price of comparable companies in the stock market [31].The challenges brought by this empirical study are: First, it shows that the IPO market is not effective, and that the market is effective is precisely the theoretical premise of these explanations; second, it shows that IPO stocks are actually issued at a "premium" (the issue price is higher than the stock price). The socalled "underpricing" is only relative to the after-market price.

\section{MEDIA}

\subsection{From information asymmetry hypothesis to investor sentiment hypothesis}

Information asymmetry is a classic theory to explain IPO underpricing. Previous studies believe that the IPO process is affected by information asymmetry among underwriters, issuers and investors. When the IPO price 
is too high, the informed investors will leave the market, and the issuer has to underprice the IPO in order to compensate for the loss of the uninformed investors caused by the uncertainty in advance. However, media reports have effectively alleviated the problem of information asymmetry among investors. The so-called uninformed investor usually refers to the individual investor, because they lack access to information or cannot timely capture the market information, so they rely on the media to collect the information of the IPO company. Zhang et al. discussed the influence of media coverage in different periods before IPO on IPO performance and the role of media in IPO process [32]. After controlling the sample self-selection bias, it has been found that the short-term media coverage between the IPO announcement date and the IPO underpricing and the first-day turnover rate are significantly positively correlated, which is in line with the investor sentiment hypothesis. The long-term media report one year before the IPO announcement is also significantly positively correlated with IPO underpricing, but there is no significant relationship with the first-day turnover rate, and the information asymmetry hypothesis is not supported. This paper believes that the unsupported information asymmetry hypothesis may be related to the phenomenon that the market focuses on emotional investment while neglecting value investment.

\subsection{Media reports and IPO underpricing}

Niederhoffer studied the economic news events in the New York Times and found that news events could significantly affect the stock prices in the capital market by examining the reaction of the capital market to different news events [33]. Easley and O'Hara established a relationship model between media information and stock cross-sectional returns and found that media information has a significant positive impact on stock cross-sectional returns [34]. Fang and Peress used panel data to test the relationship between the number of media news reports of listed companies and their corresponding stock cross-sectional returns, and found that "media effect" exists in China's A stock market, that is, the low return rate of stocks with high attention [35].

$\mathrm{Hu}$ and Guan conducted a further study on the underpricing of IPO by media attention on the basis of previous studies [36]. Through empirical research, three basic conclusions are drawn:

First, there is a significant positive correlation between media attention and IPO underpricing. Specifically, media reports lead to higher IPO underpricing through the allocation of investors' "limited attention". This effect of media attention on IPO underpricing is statistically and economically significant.
Second, investor sentiment is the mediating path of media attention effect. There is a significant positive correlation between investor sentiment and underpricing rate. The higher the media attention, the higher the irrational investor sentiment in the market, the greater the excess demand for stocks, and the higher the underpricing rate of IPO. In addition, the mediating effect of investors' emotions was also tested by the mediating variable test.

Third, investor cognition is not the specific path of media attention effect. The empirical study shows that the media attention before listing cannot effectively affect the number and proportion of rational investors, and the cognitive effect path theory has no explanatory power in China's GEM.

Wang and $\mathrm{Wu}$ constructed media tone, a proxy variable to measure investor sentiment at the company level, by using positive and negative word data from mainstream financial media reports of IPO companies in different time periods before listing, and tested the impact of investor sentiment on IPO underpricing from the level of individual stocks [37]. The research results of this paper show that, compared with positive media tone, negative media tone can better explain IPO underpricing rate, first-day turnover rate and over-offering ratio. Specifically, he found that the negative tone of the media was significantly negatively correlated with the underpricing rate of IPO, the proportion of IPO overraised funds and the proportion of underwriters' fees: for every $1 \%$ decrease in the negative tone, the underpricing rate of IPO increased by $0.22 \%$, the proportion of overraised funds increased by $0.13 \%$, and the proportion of underwriters' fees increased by $1.44 \%$. They further found that issuing companies and underwriters have the motivation and incentive to promote IPO companies through the media to guide and incite investor sentiment, thus clarifying the influencing factors of investor sentiment and the channels through which it acts on asset prices.

\subsection{Cross-sectional variations}

The quiet period is an important institutional arrangement for IPO among the world, including China. Internet social network can serve as a desirable vehicle for the communication and interaction between enterprises and stakeholders in this special period. Huang and Feng investigated whether Weibo plays a role in the IPO quiet period of the company, what role it played, and the mechanism of the role [38]. The research finds that compared with non-IPO companies, IPO companies are more willing to use "We Media" to release information in the quiet period. Based on the emotional effect, we media information released by IPO companies in the quiet period will positively influence IPO underpricing. The mechanism of its influence lies in that the frequent release of we-media information attracts more attention from the public media, raise investor sentiment, brings more new 
share purchases, and finally pushes up the underpricing level of new share issuance.

In China's capital market, high-tech companies have always been the hot spot of market pursuit. It has been reported that in order to attract investors' attention, many companies have been using the name of "high-tech". Based on this, Huang and Chen construct a proxy to identify high-tech companies [39]. According to the CSRC's industry classification guidelines, Hotspot values 1 if a GEM company is in the new energy (C76), pharmaceutical and biological products (C8), computer and related equipment manufacturing (G83), communications services (G85) and computer application services (G87) industries, and equals 0 otherwise. The empirical results show that the initial underpricing of news subject companies is more influenced by media coverage.

\subsection{Mechanism}

Wang et al. selected IPO companies in Shanghai and Shenzhen from 2009 to 2011 as samples and systematically studied the influence of media information management behavior of companies on IPO pricing and underpricing rate in the primary market and its action path [40]. After controlling other influencing factors, they found that the media information management behavior of the company reduced the IPO underpricing level while increasing the IPO price, and improved the pricing efficiency of the capital market. The IPO underpricing rate would be reduced by $0.3 \%$ on average for each additional media news report of the company during the IPO building period. Furthermore, they found that the media attention had no significant effect on the first-day turnover rate, indicating that the improvement of IPO pricing efficiency by media mainly relies on its role of information dissemination, rather than through the influence of investor sentiment. The research of this paper shows that listed companies can effectively use the media as the information transmission channel to release their pricing information in a timely and active manner, and effectively improve the pricing efficiency of the market.

Niu and Ye studied the relationship between media reports and IPO underpricing from the three dimensions of media attention, media supervision and negative media opinions, taking 403 companies listed on Shenzhen SME Board from 2009 to 2012 as sample [41]. They found that the more media reports, the stronger the media attention, the higher the IPO underpricing rate; due to the small number of pessimistic media reports, although there is a negative correlation between media supervision and IPO underpricing, it is not significant statistically. Taking the ratio of the number of negative media reports to the total number of negative media reports as the proxy variable of negative media public opinion, it is found that the negative media public opinion can significantly reduce the IPO underpricing rate and effectively restrain the IPO underpricing.

\subsection{Summary}

The role of media in the capital market has always been a hot topic. This paper investigates the impact of media reports on the IPO underpricing of companies by taking advantage of the listing event of companies on the Growth Enterprise Market. The study found that as the number of media coverage increased, the underpricing of the company's initial offering increased, and even if the media only neutral coverage of the company, this phenomenon also exists. Further analysis shows that the initial underpricing of news subject companies is more influenced by media reports. When the market condition is better, the media coverage will increase the underpricing of the company's IPO more obviously. Finally, the study shows that media coverage only increases the IPO underpricing in the short term, but in the long term after IPO, the more media coverage the company has, the more obvious the stock price decline will be.

Based on the analysis of how news media affect IPO underpricing of companies, this paper has a revelation that media reports are an important factor affecting investors' decisions. Especially with the development of information network, the spread scope of media is expanding and the time limit of reports is increasing, so it has a deeper impact on investors' behavior. Secondly, the investigation of this paper also provides a new perspective for understanding IPO underpricing of listed companies in China, and provides empirical evidence on how news media affect IPO underpricing, which is helpful to understand the phenomenon of IPO high underpricing of listed companies after the reform of stock issuance and verification system and the full circulation period. Finally, this paper only investigates the impact of media coverage on IPO underpricing, which is only one aspect of the role of news media in the capital market. In order to further understand the function of media in the capital market, more studies are needed to provide new evidence from the aspects of knowledge popularization, advertising and supervision by public opinion.

\section{GOVERNMENT}

\subsection{The Regulation of Government}

\subsubsection{The Regulation of Government in China}

The phenomenon of IPO underpricing basically appears in the capital markets of all countries in the world. The phenomenon of IPO underpricing will cause a large amount of funds to apply for purchase and cause the problem of low utilization of funds. The phenomenon of IPO underpricing is particularly serious in China's A 
share market. At present, scholars around the world have made great progress in the study of IPO underpricing phenomenon. Western scholars mainly analyze the problem from the perspective of information asymmetry and investor behavior. Chinese scholars conducted empirical tests on the theories of western scholars and found that these theories were not applicable in China. The research found that IPO underpricing phenomenon in China was significantly correlated with institutional control and speculation behavior. STAR market as a pilot for China's capital market reform, in the direction of marketization reform in the distribution system, so the STAR market distribution system influence on IPO underpricing rate, is to win the board reform achievements inspection, for through the reform of the system solve the problem of high rate of IPO underpricing, and judge STAR market system reform to the feasibility of the a-share market is important meaning.

Takada study the basic system reform of capital market in China, which sets up science and technology innovation board and implements registration system [42]. By comparing the new issues of A-share listed technology companies on the science and innovation board and the main board in the same period, the research finds that the science and innovation board registration system is beneficial to increase the issuing price ratio, but the degree of IPO underpricing increases rather than decreases. On the one hand, it verifies the theoretical correctness that the registration system can reduce IPO underpricing by playing the role of market pricing of IPO, which is conducive to increasing the issuing price/earnings ratio. On the other hand, as the newly established STAR market is an experimental way of incremental reform, there are significant differences between the strategic positioning and scientific and technological strength of listed companies on the science and technology innovation board and the main board, which leads to the false impression of contradiction between the results of empirical analysis and theoretical hypothesis. A similar study is done by Ma in 2020 [43]. He selects a total of 457 stocks from Shanghai and Shenzhen Stock Exchange as sample, using DID model on registration system's influence on the enterprise IPO underpricing in China. Research has shown that registration system implementation and time of delivery by item has a significant influence on IPO underpricing rate, the implementation of the registration system can effectively influence the IPO underpricing rate of the enterprise, and analyzes the corresponding reasons. The paper puts forward some policy suggestions, such as promoting the reform of registration system, perfecting laws and regulations of capital market, and reducing the proportion of individual investors.

Compared with the mature capital markets of other countries, Chinese stock market has a serious underpricing phenomenon of IPO issuance for a long time. IPO underpricing has been the research object of many scholars. Combined with the research results, IPO underpricing is not only due to the enterprise's own operation, but also due to China's special national conditions. By comparing the data of IPO underpricing in the recent five years from 2015 to 2019 , it can be found that the average underpricing rate of the same Chinese enterprises listed in China's Shanghai and Shenzhen stock markets is as high as $293 \%$, while the average underpricing rate of all Chinese enterprises listed in the United States in the same period is $11.37 \%$, which is much lower than the underpricing rate of those listed in China's Shanghai and Shenzhen stock markets [44]. The data show that the same enterprises operating in China have different underpricing rates when listed in different markets. Therefore, this paper does not consider from the perspective of accounting indicators related to business operation, but focuses on the factors affecting the underpricing from the perspective of the market background of IPO, namely government regulation. Chinese government regulation of the IPO underpricing has a unique background color, from release to the public, the government price controls, into the control of them, always exist, and several changes, IPO system in China from the authorization to inquiry system, to the registration system of the pilot reform nowadays, under the government regulation system reform has never stopped. In today's turbulent market economy, some regulations have undergone several reforms, but there are still some problems. First, it is difficult to form an effective market competition mechanism, market competition is not sufficient; Second, technological innovation is slow, and the efficiency of resource allocation needs to be improved. Therefore, it is of great significance to study the relationship between IPO underpricing and government regulation in the pilot registration system reform for the improvement of resource allocation efficiency in the securities industry. The STAR market, which opened in July 2019, is a pilot board of registration system. As of February 23, 2020,89 enterprises have successfully listed on the science and innovation board. After manual calculation and deducting the factors affecting the market on that day, the average underpricing rate of the 89 enterprises is as high as $133.63 \%$, which is lower than the average underpricing rate of $206.43 \%$ of new shares in other sectors listed in the same period. By comparison, it is found that the reform of registration system can significantly reduce the underpricing rate of Chinese new shares in IPO, but the average underpricing rate of science and innovation board is still higher than that of foreign mature capital markets. Based on 89 STAR market IPO samples, the introduction of multiple linear regression model, under the analysis of government regulation of the related factors to the influence degree of the IPO underpricing, results show that the present government regulation of factors, such as p/e ratio control, issuing price controls, issue to the waiting time and other factors have a significant influence on IPO underpricing. Put forward 
the following Suggestions, in order to further reduce the new IPO underpricing rate in our country, give full play to the allocation efficiency of the capital market, should be advocated rational investment, continue to intensify institutions to participate in, continue to open issue pricing controls, adding an aim at the requirements of the listed companies profit margins, to perfect the delisting system, implement a constraint and mechanism, to support medium underwriting securities firms carry large securities dealers to prevent underwriters from pricing monopoly and fee monopoly.

Government pricing control level has a significant relationship with IPO underpricing. Yu and Wang study the relationship between state-owned equity and IPO underpricing and its influence on the relationship between state-owned equity and IPO underpricing under different levels of government pricing control [45]. The results show that the proportion of state-owned equity is positively correlated with IPO underpricing. With the increase of government pricing control, the positive correlation between the proportion of state-owned equity and IPO underpricing is significantly weakened, or even turns to a negative correlation. The conclusion of this paper deepens our understanding of the relationship between state-owned equity and IPO underpricing, and can help us to understand the government's influence mechanism on IPO pricing.

At the same time, other scholars aim to study the change of audit system. Li and Li studies 3204 A-share non-financial IPO companies from 1993 to 2018 and investigates the impact of institutional change of IPO issuance on the degree of IPO underpricing [46]. The empirical results show that the change of audit system for four times has a significant effect on the underpricing degree of IPO, among which the "sponsor system" stage has the greatest decline. From the point of view of the pricing system, the release of the price-earnings ratio stage did not significantly reduce the degree of IPO underpricing, only the "inquiry system" effectively alleviated the IPO high underpricing problem. From the perspective of listing place, the "channel system" reform has a more significant effect on the reduction of IPO underpricing degree of listed companies in Shenzhen, while the other three institutional changes have no significant difference on the reduction of IPO underpricing degree of listed companies in Shanghai and Shenzhen. From the perspective of the actual first-day return rate of new shares, the first three institutional changes significantly reduced the actual first-day return rate of new shares, while the stage of "promoting registration system" made the actual first-day return rate of new shares show higher. This paper summarizes the reform process of the IPO system, and puts forward targeted policy suggestions based on large sample and long-term empirical research, which has reference significance for further promoting the reform of the IPO registration system.

\subsection{Political power and government behavior}

Inseparability of government and enterprise is the chronic disease of enterprises. Tian and Zhang study the Chines listed companies in 2015 [47]. In China's listed companies, the proportion of chairman and general manager with political connection is as high as $46 \%$. Taking 561 listed companies in China as research samples, the paper finds that the IPO underpricing rate of companies with political connection is as high as $129 \%$, while the underpricing rate of companies without political connection is $118 \%$. The paper further analyzes the relationship between political affiliation and IPO underpricing of companies with different property rights, and finds that political affiliation significantly intensifies IPO underpricing of state-owned listed companies, but has no significant effect on IPO underpricing of private listed companies. The paper holds that the reform goal of the Chinese government and the personal interests of the executives of state-owned enterprises have boosted the ultra-high underpricing of state-owned listed companies, and one of the preconditions for the success of China's IPO marketization reform is to constrain the political connection.

Li studies the influence of the political connection of private enterprises on its IPO underpricing based on the data of SME board listed companies from 2007 to 2015, and analyzes the influence of different political connections on IPO underpricing, and further tests the moderating effect of institutional environment on the relationship between political connection and IPO underpricing [48]. The results show that: the political connection can significantly affect the IPO underpricing rate, and the stronger the political connection, the higher the IPO underpricing of private enterprises; The influence of provincial and above political relations on IPO underpricing is significantly greater than the political relations below the provincial level; The higher degree of regional marketization, the lower degree of regional government intervention and the higher degree of environmental legal system, the lower the impact of political connection on the IPO underpricing of private enterprises.

With the continuous development of IPO registration system in China, the impact of IPO enterprises' opportunistic behavior on the capital market has become an important issue. By using 2010-2018 small and medium-sized board and gem IPO private enterprises and political correlation data, Qiu and $\mathrm{Xu}$ analysts in corporate profit forecast data released during the IPO, study the influence of political association of analyst earnings forecasts and affect the path , and further analyze the effect of political connection analyst earnings forecasts to the consequences of the enterprise, and then provide relevant suggestions for the regulatory layer to promote the registration system reformation [49]. The results show that the political association of senior 
executives has a significant negative impact on the optimism of the analysts' earnings forecast, which causes errors in the results of the analysts' earnings forecast. The self-interested behavior of executives' political affiliations that affect the enterprise value is the path that affects the optimism of analysts' earnings forecast. The optimism of analysts' earnings forecasts played a mediating role between political connections and IPO underpricing.

It is well established that a link exists between a country's legal system and the size, liquidity, and value of its capital markets. Beck et al. study how differences in country-level governance affect the IPO underpricing [50]. Examining 4462 IPOs across 29 countries from 2000 to 2004, the paper finds the surprising result that underpricing is higher in countries with corporate governance that strengthens the position of investors relative to insiders. This paper conjectures that when countries give outsiders more influence, IPO issuers underprice more to generate excess demand for the offer, which in turn leads to greater ownership dispersion and reduces outsiders' incentives to monitor the behavior of corporate insiders. In other words, underpricing is a cost that insiders pay to maintain control in countries with legal systems designed to empower outsiders. Consistent with this control motivation for underpricing, it has been found that underpricing has a negative association with post-IPO outside block holdings and a positive association with private control benefits. In addition, firms whose insiders are entrenched either by majority ownership or by dual-class structures do not underprice more in countries with better governance. In these firms the ownership structure protects managers from outside influence, eliminating the incentive to increase outside ownership dispersion through underpricing.

This study investigates the impact of local corruption on IPO underpricing. Wang Xin and his team find that compared to firms located in regions with low corruption, firms located in regions with high corruption exhibit higher IPO underpricing [51]. In cross-sectional analysis, this study finds that high-reputation underwriters and auditors can attenuate the positive relationship between local corruption and IPO underpricing. In addition, it also finds that the positive relationship between local corruption and IPO underpricing is confined to non-stateowned firms. This study contributes to the literature on the consequences of corruption and the determinants of IPO underpricing.

Apart from Chinese stock market, some scholars focus on the world stock market. Baker et al. study the association between environmental, social, and governance (ESG) government risk management and firm-level IPO underpricing. Examining 7446 IPOs issued in 36 countries from 2008 and 2018, the paper finds that IPO underpricing tends to be lower in countries with higher ESG Government Ratings [52]. When uniquely examining the environmental, social, and governance pillars, it has been found that underpricing tends to be lower in countries with stronger risk management practices in each of these areas. Additional analysis indicates that the negative impact of ESG ratings on IPO underpricing is more pronounced in countries with more transparent financial disclosures, higher liability standards, and stronger shareholder protections. Meanwhile, Duong et al. use a larger sample of 13,459 IPOs from 37 countries, which shows that trading rules on market manipulation reduce IPO underpricing [53]. The effect is weaker for IPOs certified by reputable intermediaries, in countries with greater shareholder rights protection, better financial reporting quality, and after the adoption of International Financial Reporting Standards. Better trading rules on market manipulation are also related to higher IPO proceeds, subscriptionlevel, and trading volume, lower IPO listing fees, and better long-term post-IPO performance. The findings are consistent with the notion that exchange trading rules mitigate information asymmetry problems for investors, resulting in lower IPO underpricing.

Colak et al. specify their study on the United States. Greater partisan alignment among lawmakers enhances their ability to respond rapidly to adverse shocks, but it also undermines the quality of checks and balances and encourages excessive governmental intervention in local areas aligned with the ruling party. Colak Gonul and his team also investigate how this form of local policy risk affects IPO underpricing [54]. An increase of one standard deviation in the political alignment between local politicians and the federal government would mean an additional $\$ 1.58$ million to choose from, or $5.39 \%$ of the average valuation discount. This effect is concentrated in firms that are vulnerable to legislative interventions and has important long-term implications. This robustness analysis also shows that the baseline results are not sensitive to the inclusion/exclusion of influential states and years with high IPO activity.

\section{CONCLUSION}

This paper reviews previous studies on IPO underpricing from three aspects: information asymmetry, media reports and government behavior and policy. Three different factors have a significant impact on IPO underpricing.

Information asymmetry is a classic factor affecting IPO bargaining price, and there are many researches related to it. Although the "Winner's Curse", "signal cascading" and "information disclosure" explanations in the asymmetric information school have received empirical support, they are only necessary conditions for the theoretical explanation to be established, which are by no means sufficient. Moreover, empirical research itself is constantly deepening. The emergence of new empirical results may cause people to re-examine those theories that 
have received empirical support. The empirical results of Purnanandam and Swaminathan show that, from 1980 to 1997 , the issue price of IPO stocks in the US market was $50 \%$ higher than the trading price of comparable companies in the stock market.[31] The challenges brought by this empirical study are: First, it shows that the IPO market is not effective, and that the market is effective is precisely the theoretical premise of these explanations; second, it shows that IPO stocks are actually issued at a "premium" (the issue price is higher than the stock price). The so-called "underpricing" is only relative to the after-market price.

The media in the capital market has a significant influence on the IPO underpricing. Underpricing of the IPO increases as the amount of media coverage increases, even when media coverage of the company is neutral. Further analysis shows that the initial underpricing of news subject companies is more influenced by media reports. When market conditions are good, media coverage can significantly increase the underpricing of the company's IPO. Finally, the study shows that media coverage only increases IPO underpricing in the short term, but in the long term after the IPO, the more media coverage, the more significant the price decline. This paper only examines the impact of media coverage on IPO underpricing, which is only one aspect of the role of news media in the capital market. In order to further understand the role of media in the capital market, more studies are needed to provide new evidence from the aspects of knowledge popularization, advertising and supervision by public opinion.

The government behavior policy of the country has a significant impact on IPO underpricing. The implementation of the registration system and the time of itemized delivery have a significant impact on the IPO underpricing rate. The implementation of the registration system can effectively affect the IPO underpricing rate of enterprises, and the corresponding reasons are analyzed. Suggestions were put forward to promote the reform of the registration system, improve the laws and regulations of the capital market, and reduce the proportion of individual investors. Government pricing control level has a significant relationship with IPO underpricing. With the increase of government pricing control, the positive correlation between the proportion of state-owned equity and IPO underpricing is significantly weakened, or even turns to a negative correlation. Inseparability of government and enterprise is the chronic disease of enterprises. Underpricing is higher in countries with corporate governance that strengthens the position of investors relative to insiders. The analysis of China's stock market is very comprehensive, and there is room for improvement in the study of other regions in the world.

\section{REFERENCES}

[1] Ritter J. R., Welch I. A Review of IPO Activity,Pricing, and Allocations[J]. The Journal of Finance,2002,57( 4) : 1795-1828

[2] Ljungqvist A. IPO Underpricing: A Survey[M]. In Handbook of Corporate Finance,Volume 1: Empirical Corporate Finance,B.

Espen Eckbo,( Editor) ,New York: Elsevier / NorthHolland,2008

[3] Ibbotson R. G. Price Performance of Common Stock New Issues[J]. Journal of Financial Economics, $1975,2(3): 235-272$

[4] Ibbotson R. G. ,Jaffe J. J. “Hot Issue” Markets[J]. The Journal of Finance,1975,30( 4) : 1027-1042

[5] Tang Yong, Luan Tianhong. Information, System and Irrational Behavior-Main Schools and Research Prospects of IPO Underpricing Theory[J].Economic Issues, 2007(12):9-12.

[6] Rock K. Why New Issues are Underpriced[D]. University of Chicago,Ph. D. Dissertation,1982

[7] Rock K. Why New Issues are Underpriced[J]. Journal of Financial Economics,1986,15( 1) : 187-212

[8] Francis Koh T W. A direct test of Rock's model of the pricing of unseasoned issues[J]. Journal of Financial Economics, 1989, 23(2): 251-272

[9] Levis M. The winner's curse problem, interest costs and the underpricing of initial public offerings[J]. The Economic Journal, 1990, 100(399): 76-89

[10] Keloharju M. The winner's curse, legal liability, and the long-run price performance of initial public offerings in Finland[J]. Journal of Financial Economics, 1993, 34(2): 251-277.

[11] Welch I. Sequential sales, learning, and cascades[J]. The Journal of finance, 1992, 47(2): 695-732.

[12] Amihud Y, Hauser S, Kirsh A. Allocations, adverse selection, and cascades in IPOs: Evidence from the Tel Aviv Stock Exchange[J]. Journal of Financial Economics, 2003, 68(1): 137-158.

[13] Benveniste L M, Spindt P A. How investment bankers determine the offer price and allocation of new issues[J]. Journal of financial Economics, 1989, 24(2): 343-361

[14] Benveniste L M, Wilhelm W J. A comparative analysis of IPO proceeds under alternative regulatory environments[J]. Journal of financial economics, 1990, 28(1-2): 173-207.

[15] Sherman A E, Titman S. Building the IPO order book: underpricing and participation limits with 
costly information[J]. Journal of Financial economics, 2002, 65(1): 3-29.

[16] Hanley K W. The underpricing of initial public offerings and the partial adjustment phenomenon[J]. Journal of financial economics, 1993, 34(2): 231250

[17] Cornelli F, Goldreich D. Bookbuilding and strategic allocation[J]. The Journal of Finance, 2001, 56(6): 2337-2369.

[18] Cornelli F, Goldreich D. Bookbuilding: How informative is the order book?[J]. The Journal of Finance, 2003, 58(4): 1415-1443.

[19] Baron D P, Holmström B. The investment banking contract for new issues under asymmetric information: Delegation and the incentive problem[J]. The Journal of Finance, 1980, 35(5): $1115-1138$

[20] Baron D P. A model of the demand for investment banking advising and distribution services for new issues[J]. The journal of finance, 1982, 37(4): 955976.

[21] Muscarella C J, Vetsuypens M R. A simple test of Baron's model of IPO underpricing[J]. Journal of financial Economics, 1989, 24(1): 125-135.

[22] Ljungqvist A, Wilhelm Jr W J. IPO pricing in the dot-com bubble[J]. The Journal of Finance, 2003, 58(2): 723-752

[23] Allen F, Faulhaber G R. Signalling by underpricing in the IPO market[J]. Journal of financial Economics, 1989, 23(2): 303-323.

[24] Welch I. Seasoned offerings, imitation costs, and the underpricing of initial public offerings $[\mathrm{J}]$. The Journal of Finance, 1989, 44(2): 421-449.

[25] Jegadeesh N, Weinstein M, Welch I. An empirical investigation of IPO returns and subsequent equity offerings[J]. Journal of Financial Economics, 1993, 34(2): 153-175.

[26] Zhang Shidi, Lu Yuehui. An Empirical Study on The Effectiveness of "Winner's Curse" and Risk Hypothesis on IPO Underpricing In China's A-Share Market[J].Management Review,2014,26(08):42-52.

[27] Liu Jing, Chen Xuan. Empirical Test of IPO Underpricing Based on Information Asymmetry Theory[J].Journal of Yunnan University of Finance and Economics,2008(05):65-72

[28] Chen Liang. Information Asymmetry, Accounting Conservatism and IPO Underpricing[J]. Economic Survey, 2014, 31(06): 108-113.
[29] Levis M. The winner's curse problem, interest costs and the underpricing of initial public offerings[J]. The Economic Journal, 1990, 100(399): 76-89.

[30] Liu Jianlei,Li Yuan.Research on The Impact of Marketization Process on IPO UnderpricingBased on The Perspective of Information Asymmetry Theory[J].Journal of International Finance,2019(06):87-96.

[31] Swaminathan B, Purnanandam A. Are Ipos Really Underpriced?[J]. Review of Financial Studies, 2004, 17: 811-848.

[32] Zhang Yahui, Wan Difang, Fu Leiming. Media Coverage and IPO Performance: Information Asymmetry or Investor Sentiment? -- Research on The Listed Companies on The Gem [J]. Securities Market Review,2012(01):70-77.

[33] Niederhoffer V. The Analysis of World Events and Stock Prices: Introduction and Summary[J]. Journal of Business, 1971,44( 1) : 193-212.

[34] Easley D,O'hara M. Information and the Cost of Capital[J]. Journal of Finance,2004,59( 4) : 15531583.

[35] Fang L,Peress J. Media Coverage and the CrossSection of Stock Returns[J]. The Journal of Finance,2009,64(5) : 2023-2052.

[36] Hu Yuncheng, Guan Chao. Research on the Influence Path of Media Concerns on IPO Underpricing -- Empirical Evidence Based on Growth Enterprise Market [J]. Business Economics and Management,2014(04):83-91.

[37] Wang Changyun, Wu Jiawei. Media Tone, Investor Sentiment and IPO Pricing [J]. Financial Research,2015(09):174-189.

[38] Huang Hongbin, Feng Huiqun. "We Media Information Disclosure In IPO Silent Period" : A Study Based on Information and Emotion Effect [J]. Journal of Shanxi University of Finance and Economics,2020,42(04):32-46.

[39] Huang Jun, Chen Xinyuan. Media Reports and IPO Underpricing -- Empirical Evidence from Growth Enterprise Market [J]. Journal of Management Science,2013,16(02):83-94.

[40] Wang Changyun, Wu Jiawei, Sun Yanmei, Gan Shunli. Corporate Media Information Management and IPO Pricing Efficiency $[\mathrm{J}]$. Management World,2015(01):118-128.

[41] Niu Feng, Ye Yong. Do Media Reports Affect IPO Underpricing of Small and Medium-Sized Board Companies? [J]. Contemporary Finance and Economics,2015(02):76-84. 
[42] Takada. Research on The Impact of Science and Technology Innovation Board Registration System on The Underpricing of Enterprises [J]. Prices in China,2020(11):74-77.

[43] Ma Yiyuan. Research on The Impact of Registration System on IPO Underpricing -- Based on The Analysis of DID Model [J]. Gansu Finance,2020(09):63-68.

[44] Shi Zhiwei. Research on IPO Underpricing Factors [D]. Nanjing University,2016.

[45] Yu Fusheng, Wang Chengfang. State-Owned Equity and IPO Underpricing: From the Perspective of Government Pricing Control $[\mathrm{J}]$. Financial Research,2012(09):155-167.

[46] Li Qingyuan, Li Xipei. New Stock Issuance Institutional Change and IPO Underpricing In AShare Market [J]. Luojia Management Review,2020(03):66-85.

[47] Tian Lihui, Zhang Wei. Political Connection and Underpricing of Stock Issuance In China: How Do "Separating Government From Enterprise" Affect The Stock Market? [J]. Journal of Economic Research,2014,40(06):16-26+120.

[48] Li Wei. The Influence of Political Connection on IPO Underpricing of Private Firms -- The Moderating Role of Institutional Environment [J]. Technology Economics and Management Research,2018(03):93-97.

[49] Qiu Jing, Xu Xin. Do Executives' Political Connections Affect Analysts' Earnings Forecasts? - An Empirical Study on The IPO Period of Private Enterprises on SMEs Board and Gem Board. Friends of Accounting,2020(19):10-17.

[50] Beck, T., Demirgüç-Kunt, A., \& Levine, R. 2000. A New Database on The Structure and Development of The Financial Sector. World Bank Economic Review, 14 (3): 597-605.

[51] Wang Xin,Song Di. Does Local Corruption Affect IPO Underpricing? Evidence from China[J]. International Review of Economics \& Finance, 2021 (Prepublish).

[52] Baker Edward D., Boulton Thomas J., Braga-Alves Marcus V., Morey Matthew R.. Esg Government Risk and International IPO Underpricing[J]. Journal of Corporate Finance,2021,67.

[53] Duong Huu Nhan,Goyal Abhinav, Kallinterakis Vasileios, Veeraraghavan Madhu. Market Manipulation Rules and IPO Underpricing[J]. Journal of Corporate Finance,2020 (Prepublish).
[54] Colak Gonul, Gounopoulos Dimitrios, Loukopoulos Panagiotis, Loukopoulos Georgios. Political Power, Local Policy Uncertainty and IPO Pricing[J]. Journal of Corporate Finance,2021,67. 